\title{
触 New Disease Reports \\ First report of Fusarium incarnatum-equiseti species complex causing ear rot of foxtail millet in Northwest regions of China
}

\author{
Z. Zheng, Y.F. Wang, H. Bai, Z.Y. Li* and Z.P. Dong
}

Millet Institute, Hebei Academy of Agricultural and Forestry Sciences, National Foxtail Millet Improvement Centre, Minor Cereal Crops Laboratory of Hebei Province, Shijiazhuang 050035, China

*E-mail: lizhiyongds@126.com

Received: 08 May 2019. Published: 26 Aug 2019. Keywords: Fusarium identification, ITS, TEF, TUB2

Foxtail millet (Setaria italica) is one of the oldest grain crops. It is still widely cultivated in arid and semiarid regions worldwide, particularly in China and India (Bettinger et al., 2010). In 2016, ears of foxtail millet with severe symptoms of Fusarium ear rot were collected from Yulin, Shanxi Province, with an incidence of up to $10 \%$. Typical disease symptoms included ears with pink or salmon-coloured mould at the ear tip of affected plants (Fig. 1).

Diseased ears were surface-sterilised with $75 \%$ ethanol, washed three times in sterile distilled water, dried, and placed onto potato dextrose agar (PDA) medium for seven days at $23_{-}^{\circ} \mathrm{C}$ with a photoperiod of 12 hours. Colonies with abundant, loosely floccose, whitish aerial mycelium and beige pigmentation were obtained (Fig. 2). The pathogens isolated from PDA were transferred to carnation leaf agar medium to induce sporulation. After incubation for ten days at $23^{\circ} \mathrm{C}$ with a $12 \mathrm{hr}$ photoperiod, conidia were collected for morphological observation. Macroconidia were falcate, usually four to seven septa, 31 to $53 \mu \mathrm{m}$ in length. A pronounced dorsiventral curvature, tapered and elongated apical cell, and prominent foot shape were observed. The fungus was morphologically identified as Fusarium equiseti (Nelson, 1983; Leslie \& Summerell, 2006) in the Fusarium incarnatum-equiseti species complex (FIESC). To confirm the identity, the partial translation elongation factor 1 alpha (TEF) gene, rDNA internal transcribed spacer (ITS) region and $\beta$-tubulin gene (TUB2) were amplified and sequenced (Vitale et al., 2011). The sequences were deposited in Genbank (Accession Nos. MN150474, MN128581 and MN128582). BLASTn analysis against the TEF (KX663763), ITS (JF773657) and TUB2 sequences (GQ915441) revealed 93\%, 99\% and 98\% identity respectively, with known sequences of these genes in the FIESC.

Pathogenicity studies were conducted on foxtail millet cv. Zhangza9. A conidial suspension $\left(10^{5}\right.$ conidia/ml $)$ was sprayed onto the millet ears of 15 plants at first flowering. Fifteen additional plants treated with sterile distilled water were used as controls. Inoculated ears were covered with a plastic bag for three days and maintained with a paper bag at $28^{\circ} \mathrm{C}$ for 20 days. The same symptoms of Fusarium ear rot as seen in the field were produced on the inoculated plants, while control plants did not develop symptoms. The fungus was reisolated from the inoculated plants and was morphologically identical to the original isolate, thus fulfilling Koch's postulates.

It was reported four decades ago that the FIESC could infect the seeds and roots of foxtail millet (Tai, 1979). However, this pathogen has not previously been reported to cause ear rot in China. We found that the infected plants did not produce any seeds when the disease was severe.
Fusarium head blight and crown rot are two diseases of wheat caused by the same Fusarium pathogen, but different host genes are involved in conferring resistance ( $\mathrm{Li}$ et al., 2010). The FIESC has been found in other regions of China and may become prevalent. This new disease could pose an imminent threat and cause severe economic losses. Further research is urgently needed to elucidate its epidemiology, symptomatology, vector transmission and crop losses in China as well as other regions where foxtail millet is widely cultivated.

\section{Acknowledgements}

This study is financially supported by the National Natural Science Foundation of China (Grant Number: 31601373), and The Excellent Going Abroad Experts Training Program in Hebei Province (2016037). The authors would like to thank Dr Chunji Liu for his constructive suggestions during the preparation of the manuscript.

\section{References}

1. Bettinger RL, Barton L, Morgan C, 2010. The origins of food production in north China: A different kind of agricultural revolution. Evolutionary Anthropology 19, 9-21. http://dx.doi.org/10.1002/evan.20236

2. Leslie JF, Summerell BA, eds, 2006. The Fusarium Laboratory Manual. New Jersey, USA: Blackwell Publishing. http://dx.doi.org/10.1002/9780470278376

3. Nelson PE, Toussoun TA, Marasas WFO, 1983. Fusarium species: An Illustrated Manual for Identification. Pennsylvania, USA: The Pennsylvania State University Press.

4. Tai FL,1979. Sylloge Fungorum Sinicorum. Peking, China: Science Press, Academia Sinica.

5. Vitale S, Santori A, Wajnberg E, Castagnone-Sereno P, Luongo L, Belisario A, 2011. Morphological and molecular analysis of Fusarium lateritium, the cause of gray necrosis of hazelnut fruit in Italy. Phytopathology 101, 679-686 http://dx.doi.org/10.1094/PHYTO-04-10-0120

6. Li HB, Xie GQ, Ma J, Liu GR, Wen SM, Ban T, Chakraborty S, Liu CJ, 2010. Genetic relationships between resistances to Fusarium head blight and crown rot in bread wheat (Triticum aestivum L.). Theoretical and Applied Genetics 121, 941-950. http://dx.doi.org/10.1007/s00122-010-1363-0
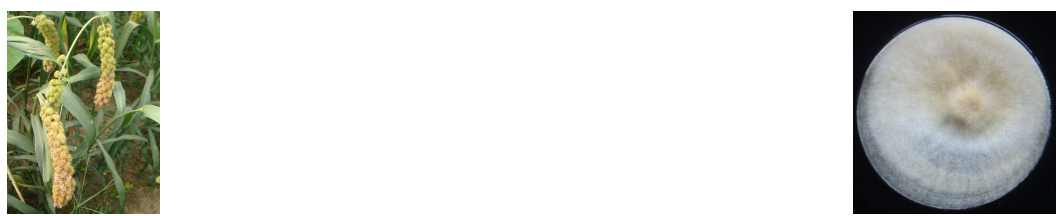

To cite this report: Zheng Z, Wang YF, Bai H, Li ZY, Dong ZP, 2019. First report of Fusarium incarnatum-equiseti species complex causing ear rot of foxtail millet in Northwest regions of China. New Disease Reports 40, 8. http://dx.doi.org/10.5197/j.2044-0588.2019.040.008 (c) 2019 The Authors This report was published on-line at www.ndrs.org.uk where high quality versions of the figures can be found. 